\title{
Súlyos fokú distalis szenzoros polyneuropathia következményeként észrevétlenül elszenvedett lábsérülések és ennek talaján elvégzett többszörös alsó végtagi amputációk - esetbemutatás
}

Vági Orsolya Erzsébet dr., Putz Zsuzsanna dr., Istenes Ildikó dr., Körei Anna Erzsébet dr., Hajdú Noémi, Kempler Péter dr.

\section{Osszefoglalás}

A szerzök diabeteses neuropathiában szenvedö betegük lábsérülésének következtében kialakult, nem gyógyuló neuropathiás fekély kórtörténetét foglalják össze esettanulmányukban. Az 59 éves férfi beteg földmunka közben észrevétlenül megsebesitette lábait, aminek következtében mindkét alsó végtagon többszöri amputációt kellett végrehajtani. Klinikánkra történö felvételekor a beteg jobb talpán egy nem váladékozó, tenyérnyi felszínes fekély volt látható. A vizsgálatok súlyos fokú, szenzoros neuropathiát igazoltak, ez alapján a korábban elvégzett minor és major amputációk dominálóan neuropathiás eredetünek voltak tekinthetök és a beteg alfa-liponsav infúziós kezelésben részesült. A sebészeti konzilium szerint a fekély aktuálisan sebészeti beavatkozást nem igényelt, a végtag polcolását és lokális kezelését javasolták. Esetünk felhivja a figyelmet arra, hogy már a cukorbetegség diagnózisának felállitásakor kiemelten fontos a lehetséges szövődményekre - igy a diabeteses lábra és annak megfeleló ápolására - felhivni a betegek figyelmét. A már kialakult fekélyek kezelése multidiszciplináris összefogást igényel, a kezelés alappillére a szénhidrát-anyagcsere egyensúlyban tartása, a neuropathia oki kezelése, a végtag tehermentesitése, valamint a rendszeres sebellátás.

Kulcsszavak: neuropathia diabetica, diabeteses láb, traumás sérülés

\section{Unobserved foot injuries and multiple amputations on both of the lower limbs due to extremly severe distal sensory polyneuropathy - case report}

Summary: Foot injury in a patient with diabetic neuropathy is reported. A 59-year-old male patient's legs had been injured by a split. The injuries have lead to multiple amputations on both of the lower extremities. The patient was admitted to our clinic with a non-healing, superficial palm size ulcer on his right sole. The minor and major amputations were the consequences of maximal degree of sensory neuropathy, the patient was treated by alpha-lipoic acid infusions. Currently there was not required any surgical intervention, the surgeon proposed only local treatment of the ulcer. Theses case demonstrates how important is to warn the patients about the potential complications (diabetic foot and its adequate care). The adequate care of the ulcers is multifactorial, the most important is the exact glycemic control, the casual therapy of the neuropathy, the off-loading of the lower limb and systematic wound care.

Key words: diabetic neuropathy, diabetic foot, traumatic injury 
z elmúlt évtizedekben egyre nagyobb fi-
gyelem fordul a diabeteses neuropathia
klinikai és prognosztikai jelentősége felé. Ennek a rossz prognózisú szövődménynek kialakulására számítanunk kell mind 1-es, mind 2-es típusú diabetes mellitus esetén. ${ }^{1,2,3}$ A diabeteses láb szindróma kialakulása szempontjából, a neuropathia tünetegyüttesén belül kiemelkedő fontosságú az alsó végtagokat érintő, distalis típusú, döntően szenzoros polyneuropathia. A szenzoros idegrostok károsodása következtében a hő-, a fájdalom- és a vibrációérzet csökkenése, esetenként teljes kiesése jellemző. ${ }^{4}$ Jellegzetes, hogy a szenzoros károsodás következtében a láb distalis része érzéketlenné válik, így a betegek sokszor észrevétlenül szenvednek el traumákat. Korábban már ismertettük egy szokatlan etiológiájú lábsérülést elszenvedett cukorbetegünk történetét. ${ }^{5}$ Egyes esetekben a motoros és az autonóm rostok károsodása, valamint egyéb tényezők (microés macroangiopathia diabetica, strukturális csontés ízületi eltérések, statikai változások, fertőzések, sérülések) is szerepet játszanak a diabeteses láb szindróma kialakulásában. ${ }^{6}$ A microcirkuláció zavara már a cukorbetegség kezdetén, egyértelmü szenzomotoros neuropathia hiányában, illetve azt megelőzően is kimutatható. ${ }^{7}$ A perifériás idegekben futó autonóm rostokat érintő neuropathia elégtelen nyugalmi perfúziót eredményez a neuropathiás láb területén, ezért a neuropathia és a perifériás érbetegség mellett a kiserek funkcionális és strukturális károsodását mint járulékos kockázati tényezőt szükséges értékelnünk a diabeteses láb kialakulása szempontjából. ${ }^{8}$ Ismertek olyan adatok is, amelyek összefüggést igazoltak a perifériás neuropathia és a csont ásványianyag-tartalmának csökkenése között. ${ }^{9}$ Az autonóm neuropathia következményeképpen kifejlődő szudomotor diszfunkció a talp bőrének kiszáradásához, így fissurák és rhagadok kialakulásához vezet, ami szintén jó alapul szolgálhat fekélyek, infekciók létrejöttéhez. ${ }^{10,11}$

\section{Esetismertetés}

Az 59 éves férfi beteg kórelőzményében 1993 óta ismert hypertonia és kezdetben orális antidiabetikummal, majd 2009-től inzulinnal kezelt 2-es tí- pusú diabetes mellitus szerepel. Aktuálisan nem dohányzott, de korábban 20 éven keresztül napi 60 szál cigarettát szívott el. Szövődményként 2008ban hypertoniás és diabeteses (non-proliferatív) retinopathia igazolódott. 2009 óta volt ismert súlyos fokú alsó végtagi szenzoros, valamint közepes fokú kardiovaszkuláris autonóm neuropathiája, ami miatt ugyanebben az évben alfa-liponsav infúziós kezelésben részesült. 2003-ban a bal alsó végtag II. ujját osteomyelitis miatt amputálták, majd 2007 és 2012 között 8 alkalommal hospitalizálták valamelyik alsó végtagon végzett amputáció miatt. Az amputációkra azt követően került sor, hogy földmunka közben nem vette észre, hogy az ásó átvágta cipője talpát és megsebesítette a lábát. 2007 októberében a jobb láb V. ujját és az V. metatarsus fejét távolították el. 2008 januárjában a jobb láb IV. ujját, májusban a jobb II. metatarsust reszekálták, végül szeptemberben a jobb láb transmetatarsalis amputációjára került sor. 2009 szeptemberében a bal láb V. ujját amputálták, majd 2010 januárjában a bal II-IV. metatarsus transmetatarsalis reszekciójára került sor. 2011. áprilisban a bal láb I. ujját távolították el, végül 2012-ben a bal alsó végtag crurális szinten történő amputációja vált szükségessé. Transzfúziót 2011 és 2012 között több alkalommal is kapott a beteg. Mellkasi panaszok miatt 2015 januárjában coronarographiás vizsgálat történt, amely negatív eredménnyel zárult. 2017 januárjában romló terhelhetőség, alsó végtagi ödémák, echocardiographián észlelt apicalis hypokinesis (EF 50-55\%) miatt a coronarographia megismétlését tervezték a betegnél. A beavatkozás előtt végzett vizsgálatok microcyter anaemiát (Hb $73 \mathrm{~g} / \mathrm{l}, \mathrm{MCV} 69$ fl), thrombocytosist $(667 \mathrm{G} / 1)$, extrém magas húgysavszintet $(672 \mu \mathrm{mol} / \mathrm{l})$, mérsékelten beszűkült vesefunkciót (kreatinin $131 \mu \mathrm{mol} / \mathrm{l}$ ) igazoltak, ami miatt a beteget további kardiológai kivizsgálás és kezelés, valamint a szénhidrát-anyagcsere rendezése céljából klinikánkra helyezték.

Felvételkor fülzúgásról és felállást követő szédülésről panaszkodott. A fizikális vizsgálat során obesitas jelei (testsúly: $128 \mathrm{~kg}$ : testmagasság: 180 $\mathrm{cm}$, testtömegindex: $39,5 \mathrm{~kg} / \mathrm{m}^{2}$ ) és orthostaticus hypotonia volt észlelhető. A jobb lábszáron ujjbenyomatot tartó anasarca volt tapintható. Az arteria dorsalis pedis és az arteria tibialis posterior a jobb lábon nem volt tapintható. A bal alsó 
végtagon cruralis amputáció per primam gyógyult sebe volt látható. Ezen a végtagon a beteg műlábat használ. A jobb lábán a transmetatarsalis amputáció csonkján kialakult, nem váladékozó, felszínes, tenyérnyi neuropathiás fekély volt látható (1. ábra), emiatt a beteg 2012 óta folyamatosan antibiotikumot (amoxicillin + clavulánsav) szedett, sebét otthon naponta kötözte. A mindkét alsó végtagján szükségessé vált orthesisviselés, valamint a gyakran már ülő helyzetben is jelentkező orthostaticus hypotonia következtében kialakult járásbizonytalanság miatt jobb lábán az orthesist nem használta, ennek következtében a fent említett fekélyen járt. Jelentős anaemiája miatt a beteg összesen 4 egység választott vörösvérsejt-koncentrátumot kapott. A beteg felvételekor készült laboratóriumi vizsgálat emelkedett éhomi vércukorértéket (glukóz: 11,7 mmol/l), emelkedett húgysavszintet (húgysav: $484 \mu \mathrm{mol} / \mathrm{l})$, CRP-t $(12,4$ $\mathrm{mg} / \mathrm{l}$ ), csökkent vasszintet (vas: $3,7 \mu \mathrm{mol} / \mathrm{l}$ ), ferritinszintet (ferritin: $11 \mu \mathrm{g} / \mathrm{l}$ ), microcyter anaemiát (Hb $67 \mathrm{~g} / \mathrm{l}, \mathrm{MCV} 73,9 \mathrm{fl}$ ) és thrombocytosist (537 giga/l) igazolt.

A neuropathia súlyosságának megítélése érdekében Neurometerrel végzett vizsgálat mindkét felső végtagon a vastag mielinizált rostok mérsékelt fokú hypaesthesiás típusú károsodását igazolta, ami mellett közepes fokú kardiovaszkuláris autonóm neuropathia is fennállt. A beteg esetében a Neurometer készülékkel történt vizsgálat már 2009-ben is maximális fokú hypaesthesiát igazolt, így az elvégzett minor és major amputációk dominálóan neuropathiás eredetűnek voltak tekinthetők. Ezek alapján a klinikán való tartózkodása során 10 napos alfa-liponsav infúziós kezelésben részesült. A sebészeti konzílium szerint a jobb talpon lévő, gyógyhajlamot nem mutató, tenyérnyi fekély aktuálisan sebészeti beavatkozást nem igényelt, a végtag polcolását és Pharma Superfoam Silver kötszerrel való kötözését javasolták. A beteg $\mathrm{HbA}_{1 \mathrm{c}}$-értéke 6,5\%-nak bizonyult, hypoglykaemiák előfordulása miatt inzulinkezelését módosítottuk (160 gramm szénhidráttartalmú diéta mellett reggel 7.00: 24 E Novorapid, 12.00: 14 E Novorapid, 17.00: 16 E Novorapid, 22.00: 36 E Levemir).

A microcytaer anaemia hátterének tisztázása érdekében elvégzett gastroscopos vizsgálat bulbitist írt le, colonoscopia elvégzésébe a beteg nem

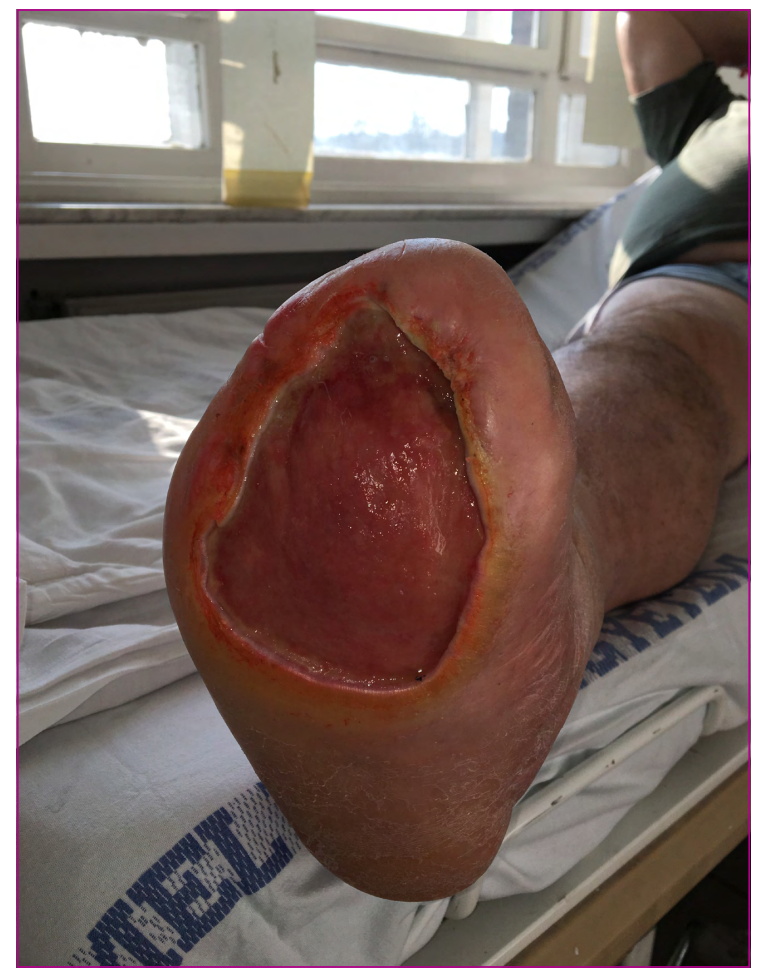

\section{1. ábra. Nem váladékozó, tenyérnyi fekély a jobb láb} talpi részén

egyezett bele, ugyanakkor véres vagy fekete székürítés, hasmenés nem fordult elő. Ezen túlmenően vasterheléses vizsgálat történt, amely során a vasfelszívódás megfelelőnek bizonyult. Mindezek alapján az anaemia elsősorban a sok éve fennálló krónikus gyulladás következményének volt tekinthető.

Távozáskor otthonában atorvastatin, pantoprazol, aspirin, amoxicillin+clavulánsav, betaxolol, furosemid, verospiron, pregabalin, perindopril + indapamid, metformin, alfa-liponsav és $\mathrm{D}_{3}$-vitamin szedését javasoltuk.

\section{Megbeszélés}

A diabeteses láb meglehetősen gyakori szövődmény, kialakulására a cukorbetegek 20-30\%-ában számítanunk kell. ${ }^{1,2,3}$ A cukorbetegek gondozása során a diabetes lehetséges krónikus szövődményeinek kockázatára mindig fel kell hívni a be- 
tegek figyelmét. Bár az érintettek többsége tudja, hogy az érzészavarnak köszönhetően szinte észrevétlenül tudnak sérülést szenvedni, fontos a láb önvizsgálatára, gondos lábápolásra, a traumák elkerülésére és a rendszeres lábtorna végzésére felhívni a betegek figyelmét. ${ }^{12,13,14}$ A cukorbetegség szövődményeként kialakuló talpi fekélyek és amputációk közel 50\%-a megelőzhető lenne a veszélyeztetett populáció időbeni azonosításával és megfelelő betegedukációval. ${ }^{10}$ A cukorbetegek körében végzett amputációk száma 15-45-ször magasabb a diabetes mellitusban nem szenvedőkön végzett beavatkozásokhoz képest. ${ }^{15}$ Az Egyesült Államokban a diabetesesek kórházi kezelésének leggyakoribb oka a diabeteses láb szindróma. Szintén az Egyesült Államokban a nem traumás eredetű alsó végtagi amputációk megközelítőleg kétharmadát cukorbetegeken végzik. ${ }^{16}$ A diabeteses láb szindrómában szenvedő betegek kezelése kitartást igényel mind a beteg, mind a kezelőorvos részéről. A diabeteses neuropathia, valamint egyéb microangiopathiás szövődmények prevenciójának és kezelésének alappillére a szénhidrát-anyagcsere egyensúlyban tartása mind 1-es, mind 2-es típusú cukorbetegség esetén (ahogyan ezt a UKPDS és DCCT tanulmány, valamint utánkövetéses vizsgálataik igazolták). ${ }^{17,18}$ A talpi fekélyek tehermentesítése az ellátás kulcsfontosságú és elengedhetetlen komponense, ${ }^{19,20,21,22,23}$ ezért az Amerikai Podiáter Társaság, az Érsebész Társaság és az Angiológiai Társaság diabeteses talpi fekély esetén a végtag tehermentesítését (off-loading) javasolja total contact cast (TCC) vagy fixált bokacsizma alkalmazásával. ${ }^{24}$ Sajnálatos módon az érintett betegek gyakran nem használják a tehermentesítő eszközöket, valamint gyakran találkozunk az irányelvekben megfogalmazott ajánlások és a klinikai gyakorlat közötti diszkrepanciával is. ${ }^{20,21,22,25,26}$ Szintén az Amerikai Podiáter Társaság, az Érsebész és Angiológiai Társaság közös ajánlása szerint a fekélyek kötözésére azok a kötszerek a legalkalmasabbak, amelyek segítenek fenntartani a nedves sebalapot, kontrollálják az exsudatumképződést és segítenek elkerülni a sebet körülvevő ép bőrfelületek felázását. Az optimális kötszer biztosítja a nedves fedést, a képződött váladék felszívódását, az autolitikus sebtisztulást, a felülfertőződés megelőzését, valamint elősegíti a granulációs folyamatokat. ${ }^{24}$
A diabeteses neuropathia patogenetikai alapokon nyugvó oki kezelésében alkalmazott két szer a benfotiamin és az alfa-liponsav, azonban fájdalmas neuropathia esetében a terápia tüneti szerekkel (pregabalin, gabapentin, duloxetin stb.) is kiegészíthető. A tüneti terápia monoterápiaként való alkalmazása azonban nem ajánlott, mert a fájdalom elfedése mellett magát a kórfolyamatot nem befolyásolja. ${ }^{27}$

A korszerű, hatékony ellátás biztosítása érdekében elengedhetetlen a társszakmák szoros együttmüködése, valamint a diabeteses láb-ambulanciák létrehozása. Az ezen a téren bekövetkezett javulást mutatja, hogy Európában az elmúlt 10-15 évben a diabeteses láb miatt végzett amputációk 37-75\%-kal visszaszorultak. ${ }^{28}$ A multidiszciplináris látásmód, valamint a társszakmák együttműködésének köszönhetően a végtagcsonkolások számának csökkenése volt megfigyelhető olyan cukorbetegek esetében, akiknél az elváltozás létrejöttében vaszkuláris komponens is szerepet játszott. ${ }^{29,30} \mathrm{~A}$ CODE vizsgálat világított rá, hogy Európában egy diabeteses beteg egy évre számított gondozási költségei szövődmények egyidejű fennállása esetén (pl. diabeteses láb szindróma) megsokszorozódnak. ${ }^{31}$ Nyilvánvaló tehát, hogy a diabeteses láb szindróma kialakulásának prevenciója nem csak az érintett beteg, hanem a társadalom anyagi teherviselése szempontjából is kiemelten fontos. ${ }^{32}$

Esetünk jól példázza, hogy már a cukorbetegség diagnózisának felállításakor kiemelten fontos a lehetséges szövődményekre - így a diabeteses lábra és annak megfelelő ápolására - felhívni a betegek figyelmét. A már kialakult fekélyek kezelésének alappillére a rendszeres kötözés megfelelő kötszerrel, valamint korszerű orthesisek, tehermentesítő eszközök használata. Összefoglalva: a diabeteses láb sikeres ellátásához diabetológus, ortopéd sebész, podiáter, diabetológiai edukátor, valamint a beteg együttmüködése elengedhetetlen. 


\section{rrodalom}

1. Fedele D, Comi G, Coscelli C, Cucinotta D, Feldman L, Ghirlanda G, et al.: A multicenter study of the prevalence of diabetic neuropathy in Italy. Italian Diabetic Neuropathy Committee. Diabetes Care 1997; 20: 836-843. doi:10.2337/diacare.20.5.836

2. Ward JD: Improving prognosis in type 2 diabetes. Diabetic neuropathy in trouble. Diabetes Care 1999; 22(Suppl 2): B84-86.

3. Cabezas-Cerrato J: The prevalence of clinical diabetic polyneuropathy in Spain: a study in primary care and hospital clinic groups. Neuropathy Spanish Study Group of the Spanish Diabetes Society. Diabetologia 1998; 41: 1263-1269. doi:10.1007//5001250051063

4. Kempler P: A diabeteses neuropathia klinikai képe és diagnosztikája. Orvosi Hetilap 2002; 143: 1113-1120.

5. Vági $\mathrm{OE}$, Putz Zs, Istenes I, Körei AE, Hajdú N, Tótok F, et al.: Fájdalmatlan lábgangraena hátterében detektált maximális mértékú szenzoros hypaesthesia és tünetmentes, súlyos fokú obliterativ veröérbetegség. Diabetologia Hungarica 2016; 24:277-270.

6. Jermendy Gy: Diabeteses láb. (In: Meskó É, Farsang (s, Pécsvárady Zs /szerk/: Belgyógyászati angiológia 1999.) Melánia Kiadó, Budapest, 287-292.

7. Krishnan ST, Quattrini C, Jeziorska M, Malik RA, Rayman G: Abnormal LDI flare but normal quantitative sensory testing and dermal nerve fiber density in patients with painful diabetic neuropathy. Diabetes Care 2009; 32: 451-455. doi:10.2337/dc08-1453

8. Sun $P C$, Kuo $C D$, Chi $L Y$, Lin $H D$, Wei $S H$, Chen CS: Microcirculatory vasomotor changes are associated with severity of peripheral neuropathy in patients with type 2 diabetes. Diab Vasc Dis Res 2013; 10: 270-276. doi:10.1177/1479164112465443

9. Kempler P: Az osteoporosis és a neuropathia összefüggései. Kalcium és Csont 2000; 3:5-10.

10. Markakis K, Bowling FL, Boulton AJ: The diabetic foot in 2015: an overview. Diabetes Metab Res Rev 2016; 32(Suppl 1): 169-178. doi:10.1002/dmrr.2740

11. Körei AE, Putz Z, Istenes I, Németh $N$, Martos $T$, Kempler $M$, et al.: A vékonyrost-neuropathia klinikai jelentösége diabetes mellitusban. Diabetologia Hungarica 2014; 1: 15-23.

12. Culleton JL: Preventing diabetic foot complications. Tight glucose control and patient education are the keys. Postgrad Med 1999; 106: 74-78.

13. Edmonds ME, Van Acker K, Foster AVM: Education and the diabetic foot. Diabetic Med 1996; 13: S61-S64.

14. El-Shazly M, Abdel-Fattah M, Scorpiglione N, Benedetti MM, Capani F, Carta Q, et al:: Risk factors for lower limb complications in diabetic patients. The Italian Study Group for the implementation of the St. Vincent Declaration. J Diab Compl 1998; 12: 10-17. doi:10.1016/51056-8727(97)00001-9

15. Apelqvist J, Ragnarson G, Persson U, Larsson J: Diabetic foot ulcers in a multidisciplinary setting. An economic analysis of primary healing and healing with amputation. J Intern Med 1994; 235: 463-471. doi:10.1111/j.1365-2796.1994.tb01104.x

16. National Institute of Diabetes and Digestive and Kidney Diseases: National diabetes statistics fact sheet: general information and national estimates of diabetes in the United States (2005).

17. The Diabetes Control and Complications Trial Research Group: The effect of intensive treatment of diabetes on the development and progression of longterm complications in insulin-dependent diabetes mellitus. N Engl J Med 1993; 329(14): 977-986. doi:10.1056/NEJM199309303291401

18. UK Prospective Diabetes Study (UKPDS) Group: Intensive blood-glucose control with sulphonylureas or insulin compared with conventional treatment and risk of complications in patients with type 2 diabetes (UKPDS 33). Lancet 1998; 352(9131): 837-853. doi:10.1016/50140-6736(98)07019-6
19. Frykberg RG, Zgonis T, Armstrong DG, Driver VR, Giurini JM, Kravitz SR, et al.: Diabetic foot disorders. A clinical practice guideline (2006 revision). J Foot Ankle Surg 2006; 45(Suppl): S1-66. doi:10.1016/51067-2516(07)60001-5

20. Bus SA: Priorities in offloading the diabetic foot. Diabetes Metab Res Rev 2012; 28 (Supp11): 54-59. doi:10.1002/dmrr.2240

21. Cavanagh PR, Bus SA: Off-loading the diabetic foot for ulcer prevention and healing. J Vasc Surg 2010; 52(Suppl): 37S-43S. doi:10.1016/j.jvs.2010.06.007

22. Lewis J, Lipp A: Pressure-relieving interventions for treating diabetic foot ulcers. Cochrane Database Syst Rev 2013; 1: CD002302. doi:10.1002/14651858.CD002302.pub2

23. Snyder RJ, Kirsner RS, Warriner RA, Lavery LA, Hanft JR, Sheehan P: Consensus recommendations on advancing the standard of care for treating neuropathic foot ulcers in patients with diabetes. Ostomy Wound Manage 2010; 56(Suppl): S1-24.

24. Hingorani A, LaMuraglia GM, Henke P, Meissner MH, Loretz L, Zinszer KM, et al: The management of diabetic foot: A clinical practice guideline by the Society for Vascular Surgery in collaboration with the American Podiatric Medical Association and the Society for Vascular Medicine. J Vascular Surg 2016; 63(2 Suppl): 10S-12S. doi:10.1016/j.jvs.2015.10.003

25. Wu SC, Jensen JL, Weber AK, Robinson DE, Armstrong DG: Use of pressure offloading devices in diabetic foot ulcers: do we practice what we preach? Diabetes Care 2008; 31: 2118-2119. doi:10.2337/dc08-0771

26. Waaijman R, Keukenkamp R, de Haart M, Polomski WP, Noller F, Bus SA: Adherence to wearing prescription custom-made footwear in patients with diabetes at high risk for plantar foot ulceration. Diabetes Care 2013; 36: 1613-1618. doi:10.2337/dc12-1330

27. Várkonyi T, Putz Z, Keresztes K, Martos T, Lengyel C, Stirban A, et al.: Current options and perspectives in the treatment of diabetic neuropathy. Curr Pharm Des 2013; 19(27): 4981-5007. doi:10.2174/13816128113199990310

28. Vuorisalo S, Venermo M, Lepäntalo M: Treatment of diabetic foot ulcers. J Cardiovasc Surg (Torino) 2009; 50: 275-91.

29. Aydin K, Isildak M, Karakaya J, Gürlek A: Change in amputation predictors in diabetic foot disease: effect of multidisciplinary approach. Endocrine 2010; 38: 87-92. doi:10.1007/s12020-010-9355-z

30. Apelquvist J: Diagnostics and treatment of the diabetic foot. Endocrine 2012; 41: 384-397. doi:10.1007/s12020-012-9619-x

31. Williams R, Van Gaal L, Lucioni C: Assessing the impact of complications on the costs of type Il diabetes. Diabetologia 2002; 45: S13-S17.

32. Reiber GE: Diabetic foot care. Financial implication and practice guidelines. Diabetes Care 1992; 15(Suppl 1): 29-31.

Közlésre érkezett: 2017. április 13.

Közlésre elfogadva: 2017. május 18.

\section{A levelezésért felelős szerző}

Dr. Vági Orsolya Erzsébet

Semmelweis Egyetem, I. Belgyógyászati Klinika

1083 Budapest, Korányi S. u. 2/a.

E-mail: vagiorsi@gmail.com 